Brit. J. prev. soc. Med. (1976), 30, 66-70

\title{
Incidence and variables contributing to onset of cigarette smoking among secondary schoolchildren and medical students in Lagos, Nigeria
}

\author{
O. O. ELEGBELEYE AND D. FEMI-PEARSE \\ Respiratory Unit, Department of Medicine, Lagos University Teaching Hospital, Lagos, Nigeria
}

\begin{abstract}
Elegbeleye, O. O. and Femi-Pearse, D. (1976). British Journal of Preventive and Social Medicine, 30, 66-70. Incidence and variables contributing to onset of cigarette smoking among secondary schoolchildren and medical students in Lagos, Nigeria. This paper reports the findings of a survey of smoking habits among secondary schoolchildren and medical students in Lagos, Nigeria. Altogether $40 \%$ of boys and $8.4 \%$ of girls at secondary school, and $72.4 \%$ of men and $22.2 \%$ of women at medical school were found to smoke. While the smoking habit of the secondary schoolboys was influenced by the smoking habits of their parents and friends, the smoking habit of the secondary schoolgirls and female medical students was mainly influenced by that of their friends. This study provides a baseline against which future studies on smoking habits in developing African countries may be measured, and the results show that health education on cigarette smoking must start in primary and secondary schools.
\end{abstract}

Cigarette smoking is common in developed countries (Tobacco Research Council, 1967), and diseases associated with cigarette smoking-such as lung cancer, myocardial infarction, and chronic bronchitis-constitute challenging problems in economically developed countries (Doll and Hill, 1952; Oswald and Medvei, 1955; United States Public Health Service, 1972). There have been few reports in the literature about the association between these diseases and cigarette smoking from developing African countries, and these indicate that lung cancer, myocardial infarction, and chronic bronchitis are rare in the African (Femi-Pearse, Adeniyi-Jones, and Oke, 1973; Elegbeleye 1975).

Little is known about the smoking habits of schoolchildren in developing African countries, although Arya and Bennett (1969) studied the smoking habits of university students in Uganda. More studies are necessary for epidemiological and comparative purposes, and this has prompted us to study the smoking habits and the variables contributing to the onset of cigarette smoking among secondary schoolchildren and medical students in Nigeria.

\section{Material AND Methods}

A total of 2030 secondary schoolchildren and 250 medical students were surveyed. Teams of trained examiners, including the authors of this: paper, went to each school. Students were asked tod complete detailed questionnaires in the classroom? while the trained examiners offered guidance and read instructions and questions to the pupils To encourage truthful replies the confidentia nature of the inquiry was stressed, and pupils were told not to write their names on the forms. The completed forms were then collected and placed in a sealed envelope by a member of the study group, and students were promised thatr neither their parents nor their teachers would see them. No attempt was made to obtain informations from those who were absent on the day of thew survey. Questionnaires were rejected in cases in? which the answers were either incomplete or confusedo

\section{QUESTIONNAIRE}

The questionnaire was divided into four partso and the subjects selected those parts that related 
to their smoking status. All subjects completed the first part which consisted of general demographic items and concluded with the definitions of the three categories of smoking behaviour (Palmer, 1970). Each student completed the questions relating to the category which best described him:

1. I never tried to smoke even one cigarette (non-smoker).

2. I have tried to smoke but I do not smoke now (experimental smoker).

3. I smoke all or most of the time (regular smoker).

\section{Results}

The analyses were based on a total of 1973 questionnaires or $96 \%$ of the total of the secondary schoolchildren; the remainder were either incomplete or incorrect. There were 232 out of 250 completed forms from the medical students, these representing the total number in the halls of residence during the long vacation when the study began.

\section{SECONDARY SchOOLCHILDREN}

Smoking Prevalence

There were 1026 boys and 947 girls. Of the boys $40 \%$ were smokers, $22 \cdot 2 \%$ experimental and $17 \cdot 5 \%$ regular. Among the girls, $8.4 \%$ were smokers, $5.7 \%$ experimental and $2.7 \%$ regular (Table $\mathrm{I}$ ). Taking both boy and girl smokers together $10.4 \%$ were regular, $14 \cdot 2 \%$ experimental, and $75 \cdot 4 \%$ non-smokers. A breakdown of regular smokers showed that virtually all were light smokers (less than $15 \mathrm{~g}$ daily).

Table II shows the smoking habits by age at the time of the survey. For the boys the proportion of regular smokers tended to increase with age, reaching $40 \%$ in the oldest group. For the girls a similar trend appeared in the three younger groups, but there were no regular smokers in those over 18 years of age.
TABLE I

SMOKING STATUS (SECONDARY SCHOOLS) FOR BOYS AND GIRLS

\begin{tabular}{ll|r|r|r|r}
\hline \multirow{2}{*}{$\begin{array}{c}\text { Smoking } \\
\text { Status }\end{array}$} & \multicolumn{2}{c|}{ Boys } & \multicolumn{2}{c}{ Girls } \\
\cline { 3 - 6 } Non-smoker & $\ldots$ & No. & $\%$ & No. & \multicolumn{1}{c}{$\%$} \\
Experimental & $\ldots$ & 227 & $22 \cdot 2$ & 54 & $5 \cdot 7$ \\
Regular & $\ldots$ & 180 & $17 \cdot 5$ & 26 & $2 \cdot 7$ \\
\hline \multirow{2}{*}{ Total..} & $\ldots$ & 1026 & 100 & 947 & 100 \\
\hline
\end{tabular}

Age of First Smoke and Regular Smoking

Table III shows the age of first smoke and regular smoking among secondary schoolchildren. Most of the boys and girls who smoked had their first attempt when between 10 and 17 years and then became regular smokers between 14 and 17 years.

ANALYSIS OF HARMFUl EFFECTS: REASONS FOR Smoking and Parental ObJection to SMoking A large variety of harmful effects were mentioned. Altogether $65 \%$ mentioned cancer of the lung; while $85 \%$ of boys and $75 \%$ of girls mentioned

TABLE III

AGE AT WHICH SECONDARY SCHOOLCHILDREN STARTED TO SMOKE

\begin{tabular}{|c|c|c|c|c|}
\hline & \multicolumn{2}{|c|}{ Boys } & \multicolumn{2}{|c|}{ Girls } \\
\hline $\begin{array}{c}\text { Age } \\
\text { (years) }\end{array}$ & $\begin{array}{l}\text { No. having } \\
\text { first smoke }\end{array}$ & $\begin{array}{c}\text { No. starting } \\
\text { regular } \\
\text { smoking }\end{array}$ & $\begin{array}{l}\text { No. having } \\
\text { first smoke }\end{array}$ & $\begin{array}{c}\text { No. starting } \\
\text { regular } \\
\text { smoking }\end{array}$ \\
\hline $6-9$ & 11 & - & - & - \\
\hline $10-13 \ldots$ & 159 & 26 & 23 & 5 \\
\hline $14-17 \ldots$ & 202 & 137 & 53 & 19 \\
\hline $18+\ldots$ & 13 & 17 & 4 & 2 \\
\hline
\end{tabular}

TABLE II

SECONDARY SCHOOLCHILDREN: AGE AND TYPE OF SMOKER

\begin{tabular}{|c|c|c|c|c|c|c|c|c|c|c|}
\hline \multirow{2}{*}{\multicolumn{2}{|c|}{ Smoking Status }} & \multirow[b]{2}{*}{$\cdots$} & \multicolumn{2}{|c|}{$10-12$ years } & \multicolumn{2}{|c|}{ 13-15 years } & \multicolumn{2}{|c|}{$16-18$ years } & \multicolumn{2}{|c|}{$19+$ years } \\
\hline & & & Boys & $\underset{\%}{\text { Girls }}$ & Boys & $\underset{\%}{\text { Girls }}$ & $\begin{array}{c}\text { Boys } \\
\%\end{array}$ & $\underset{\%}{\text { Girls }}$ & Boys & Girls \\
\hline Non-smoker & . & . & $68 \cdot 1$ & $95 \cdot 8$ & $52 \cdot 9$ & $88 \cdot 9$ & $65 \cdot 1$ & & $53 \cdot 5$ & $94 \cdot 1$ \\
\hline Experimental & $\cdots$ & .. & $25 \cdot 5$ & $3 \cdot 4$ & $26 \cdot 3$ & $8 \cdot 2$ & $21 \cdot 3$ & $4 \cdot 3$ & $7 \cdot 0$ & $5 \cdot 9$ \\
\hline Regular & . & . & $6 \cdot 4$ & $0 \cdot 8$ & $20 \cdot 7$ & $2 \cdot 8$ & $13 \cdot 6$ & $10 \cdot 3$ & $39 \cdot 5$ & 一 \\
\hline Total number & $\cdots$ & . & 235 & 356 & 338 & 389 & 324 & 117 & 129 & 85 \\
\hline
\end{tabular}


coughs and bronchitis. Other harmful effects included bad breath and black lung. About 5\% stated that they did not know of any harmful effects. The majority of the parents of both smokers and non-smokers objected strongly to smoking. Over $50 \%$ of both boys and girls mentioned pleasure, fun, and relaxation as being their reason for smoking, while $65 \%$ of boys and $58 \%$ of the girls smoked because their friends smoked; another $30 \%$ of the boys and $15 \%$ of the girls smoked for concentration and nervousness (Table IV).

Table IV

HARMFUL EFFECTS, REASONS FOR SMOKING, AND OBJECTION BY PARENTS TO SMOKING

\begin{tabular}{|c|c|c|c|c|c|}
\hline \multirow[b]{4}{*}{$\begin{array}{l}\text { Harmful effects of smoking } \\
\text { Lung cancer } \\
\text { Cough/bronchitis/heart attacks } \\
\text { Miscellaneous } \\
\begin{array}{l}\text { No harm } \quad . . \\
.\end{array}\end{array}$} & \multirow[b]{4}{*}{$\begin{array}{l}\ldots \\
\because \\
\cdots\end{array}$} & \multicolumn{4}{|c|}{ Secondary School } \\
\hline & & \multicolumn{2}{|c|}{ Boys } & \multicolumn{2}{|c|}{ Girls } \\
\hline & & No. & $\%$ & No. & $\%$ \\
\hline & & $\begin{array}{r}615 \\
972 \\
615 \\
51\end{array}$ & $\begin{array}{r}60 \\
95 \\
60 \\
5\end{array}$ & $\begin{array}{r}616 \\
710 \\
170 \\
19\end{array}$ & $\begin{array}{r}65 \\
75 \\
18 \\
2\end{array}$ \\
\hline $\begin{array}{cc}\text { Parental objection } \\
\text { Fathers } & \ldots \\
\text { Mothers } & \ldots\end{array}$ & 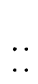 & $\begin{array}{l}769 \\
974\end{array}$ & $\begin{array}{l}75 \\
95\end{array}$ & $\begin{array}{l}805 \\
919\end{array}$ & $\begin{array}{l}85 \\
97\end{array}$ \\
\hline $\begin{array}{l}\text { Reasons for smoking } \\
\text { Pleasure, fun, relaxation } \\
\text { Because friends smoke } \\
\text { For concentration, } \\
\text { nervousness, etc. }\end{array}$ & $\begin{array}{l}\cdots \\
\cdots \\
\cdots\end{array}$ & $\begin{array}{l}224 \\
265 \\
122\end{array}$ & $\begin{array}{l}55 \\
65 \\
30\end{array}$ & $\begin{array}{l}52 \\
46 \\
12\end{array}$ & $\begin{array}{l}65 \\
58 \\
15\end{array}$ \\
\hline
\end{tabular}

Influence of Smoking by Parents AND Friends

More fathers smoked than mothers, regardless of the students' smoking status, but parental smoking habits had a significant influence on the smoking habits of young secondary school boys $(P<0.005$ for both fathers and mothers).

SMOKING Among FRIENDS

Similarly, the smoking habits of friends had a significant influence on the smoking habits of secondary schoolchildren, both boys and girls $(P<0.005)$.

\section{Smoking Prevalence}

\section{Medical Students}

There were 232 students, 196 men and 36 women. While $72.4 \%$ of the men smoked only $22.2 \%$ of the women smoked, although the number of the women was too small for any definitive conclusion (Table V).
TABLE V

SMOKING STATUS: FOR MALE AND FEMALE MEDICAL STUDENTS

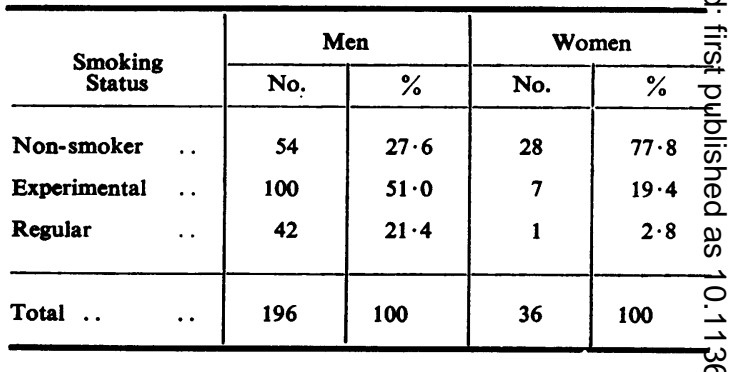

The proportion of regular smokers was greate? in the older men, over 24 years of age, but there were too few women for any age trend to be discernible.

Most of the men had had their first smokes when between 14 and 18 years of age; while most of the women had had their first smoke when between 10 and 17 years of age. The majority of the smokers became regular smokers after 18 years of age. By contrast with the secondary school $=$ children the smoking habits of ihe parents had no influence on the smoking habits of the medieap students.

While the smoking habits of the male medieas students were not influenced by those of thei friends, the smoking habits of the female medicab students were.

HaRmful EFFects and Reasons for SMOKIng

Table VI shows that most of the parents of the medical students objected to smoking. As regards harmful effects more medical students than secondary schoolchildren mentioned lung cancer, bron』 chitis, and coughs. While most of the male medical students smoked for pleasure, relaxation and concentration, $75 \%$ of the female medical students smoked because their friends smoked.

\section{Discussion}

There have been several studies to ascertain the smoking habits of schoolchildren in developed countries (Chave and Schilling, 1959; Nilsen; 1959; Palmer, 1970; Bewley, Bland, and Harris 1974).

This study showed that the incidence of cigaretter smoking was $25 \%$ among secondary schoolchildreno and $65 \%$ among medical students. There were now similar studies in secondary schools to the best? of our knowledge in African countries. Most of the studies on cigarette smoking among school: children from developed countries reported a highe 
TABLE VI

HARMFUL EFFECTS, REASONS FOR SMOKING, AND OBJECTION BY PARENTS TO SMOKING

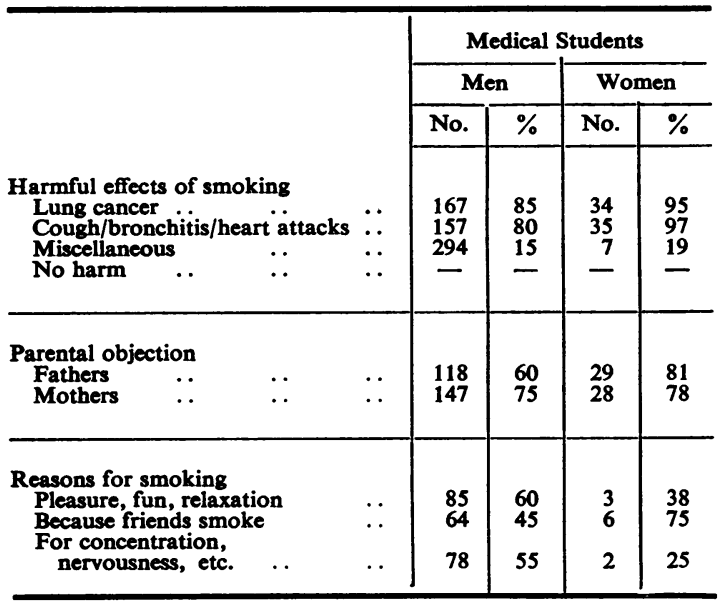

incidence of $35 \%$ and above among boys or both sexes (Nilsen, 1959; Chave and Schilling, 1959; Salber and MacMahon, 1961; Palmer, 1970). However, there have been a few reports on the smoking habits of adults in developing African countries. Femi-Pearse et al. (1973) reported their findings in a random survey of the population of Lagos that among men (20 years and older) $41 \%$ were cigarette smokers, the figures for other studies were $51.5 \%$ among 35 and 54-year-old Africans in a Guyana village (Miller and Ashcrott, 1971), and $31.5 \%$ among African university students in Uganda (Arya and Bennett, 1969). In this study when the smokers were divided into regular and experimental smokers, it was found that $10.4 \%$ of the secondary schoolchildren were regular smokers while $14 \cdot 2 \%$ were experimental smokers. Among the medical students $19 \%$ were regular smokers while $46 \%$ were experimental.

Our study also showed that the smoking habits of the secondary schoolchildren were related to the smoking habits of their parents. Studies of adolescent smoking have demonstrated that in cases in which both parents smoked the children were more likely to smoke (Cartwright and Thomson, 1960; Salber and MacMahon, 1961). Bynner (1969) and Holland et al. (1969) showed that boys smoked more and started smoking earlier than girls and also that the extent to which they smoked increased with age. It is interesting that most of the secondary schoolchildren who smoked had friends who were smokers. Thus an important factor contributing to the onset of cigarette smoking among Nigerian students is the fact that they had friends who smoked. This was also true of the medical students.

The reasons given by smokers for their smoking were similar to those given by subjects studied by Arya and Bennett (1969), the most common being pleasure, concentration, relaxation, and social (Table IV).

In their analyses of harmful effects of smoking, the majority of students mentioned cancer of the lung and cough; this was probably a reflection of their education. Furthermore, most medical students mentioned bronchitis and heart attacks as harmful effects.

This study showed that the incidence of cigarette smoking among secondary schoolchildren in Nigeria was significant, although not as high as those reported from developed countries. With improved cash economy consequent upon industrialization of several African towns, the smoking habit will increase. In order to prevent the diseases associated with cigarette smoking, this study showed that efforts should be made to start health education in Africa at primary and secondary school levels. Finally this study provided a baseline against which future studies on smoking habits in developing African countries might be measured.

Our profound gratitude goes to all the headmasters of the secondary schools who took part in this survey. We also thank Mrs $K$. O. Williams and all field workers who helped in the study, Mr A. Sodimu and Mrs S. I. Ayeni for secretarial assistance.

Address for reprints: O. O. Elegbeleye, Senior Medical Registrar, Respiratory Unit, Department of Medicine, Lagos University Teaching Hospital, Private Mail Bag 12003, Lagos, Nigeria.

\section{REFERENCES}

ARYA, O. P. and BENNETT, F. J. (1969). Smoking among university students in Uganda. East Afr. med. J., 47, 18.

Bewley, B. R., Bland, J. M., and Harris, R. (1974). Factors associated with the starting of cigarette smoking by primary school children. Brit. J. prev. soc. Med., 28, 37.

BYNNER, J. M. (1969). The Young Smoker. Government Social Survey. HMSO, London.

Cartwright, A. and Thomson, J. G. (1960). Young smokers: an attitude study among school children, touching also on parental influence. Brit. J. prev. soc. Med., 14, 28.

Chave, S. P. W. and Schilling, R. (1959). The smoking habits of school children. Brit. J. prev. soc. Med., 13, 1. 
Doll, R. and Hill, A. B. (1952). A study of the aetiology of carcinoma of the lung. Brit. med. J., 2, 1271.

Elegreleye, O. O. (1975). Bronchial carcinoma in Nigerians. J. trop. Med. Hyg., 78, 59.

Femi-Pearse, D., Adeniyi-Jones, A., and Oke, A. B. (1973). Respiratory symptoms and their relationship to cigarette smoking. Dusty occupations and domestic air pollution: studies in random sample of an urban African population. W. Afr. med. J., 22, 57.

Holland, W. W., Halil, T., Bennett, A. E., and Elliotr, A. (1969). Factors influencing the onset of chronic respiratory disease. Brit. med. J., 2, 205.

Miller, G. J. and ASHCrotT, M. T. (1971). A community survey of respiratory disease among East Indian and African adults in Guyana. Thorax, 26, 331.
NILSEN, E. (1959). Smoking habits among school children in Norway. Brit. J. prev. soc. Med., 13, 53

Oswald, N. C. and Medvei, V. C. (1955). Chroniẹ? bronchitis. The effect of cigarette smoking. Lancet $2,843$.

Palmer, A. B. (1970). Some variables contributing to을 the onset of cigarette smoking among junior high school students. Soc. Sci. and Med., 4, 359.

Salber, E. J. and MacMahon, B. (1961). Cigarette $\overparen{D}$ smoking among high school students related socia class and parental smoking habits. Amer. J. publ. Hlth, 51, 1780.

Tobacco Research Council (1967). Review of Activities $\overrightarrow{\vec{w}}$ 1963.1966. Tobacco Research Council, London

United States Public Health Service (1972). The Health Consequences of Smoking. A report of the Surgeon General. US Department of Health,O Education and Welfare. D. Hew Publication No.(H.S.M.), 72-75, 16. 